\title{
Corporate Social Responsibility In Islamic Banking Institutions In Aceh: Analysis Of Criteria And Perception ${ }^{1}$
}

\author{
Zakaria Bahari2 \\ E-mail: bzak@usm.my \& bzak09@gmail.com. \\ Phone: +6046532664
}

Muhammad Yasir Yusuf 3

E-mail: m.yasiryusuf@gmail.com

Phone: +62-81269838 803

\section{Doi:10.5901/jesr.2014.v4n2p390}

\section{ABSTRACT}

The concept of corporate social responsibility (CSR) emerged in the West in 1970s' and had become an emerging issue of discussion among the researchers. The concept of CRS was initiated on humanitarian grounds which can be traced back to human norms, and culture in the West. It becomes questionable when the same concept, based on western paradigm, is adopted and implemented for the Islamic banking institutions. Islamic banks are assumed to follow their own worldview concept of welfare rather to rely on conventional CRS concept. This paper attempts to identify the alternate concept of CSR in the Islamic perspective. Notwithstanding, the alternate concept of CRS for the Islamic banking institutions, the study also investigates customers' perceptions of the Islamic Banks in Aceh towards CSR. The study is divided into two phases. The first phase of the study is theoretical and based on library materials. Content analysis method has been used to investigate the material and deduce results. The second phase is based on interviews with experts and 400 customers' responses about their perceptions regarding CSR in Islamic banking Institutions (IBIS) in Aceh. The findings of the study can be summarized as: there is no direct verse or tradition of the holy prophet regarding CSR however, there are plenty verses which show that individuals and institutions are responsible for any damage they caused to the society or environment. Findings of the study suggest that the concept of CSR is different from traditional paradigm. The CSR concept in Islam is practiced in three areas of responsibility; first, responsibility to God second, responsibility towards the people, and third, responsibility to the environment. These three levels are supported by the basic principles of monotheism (tauhid), the caliphate (khalifah), justice, brotherhood (ukhuwwah) and maslahah. The study used six criteria based on 34 items to measure CSR performance of the IBIs. These are namely; Syariah compliance, equality, working responsibility, the guarantee of prosperity, the guarantee of environmental sustainability and charity for preservation of virtue. Findings of the second phase of the study indicate that the customers perceptions regarding the Syariah banking CSR practices in Aceh are high. The customers make Syari'ah compliance criteria as the main criteria in the selection of the IBIS.

Keywords: Islamic Corporate Social Responsibility, Islamic Banking, Criteria and Perception

\section{Background}

Bowen (1953) defines Corporate Social Responsibility (CSR) as a corporate decision impart benevolence to the community, but Fredrick (1960) defines CSR as the use of community resource, economic and human beings as a whole to maximize the productivity of society in addition to corporate profits and corporate owners. The concept of corporate social responsibility $(\mathrm{CSR})^{4}$ is the responsibility of corporate to create a sustainable economic development through the effort of improving the quality of life and environment (Dusuki and Dar 2005; Hay and Gray 1974; Obaloha 2008).

${ }_{1}$ Paper present at the $13^{\text {th }}$ Simposium Kebudayaan Malaysia (SKIM), organized by Universitas Padjadjaran (UNpad) and Universiti Kebangsaan Malaysia (UKM), Universitas Padjadjaran Jatinangor, Bandung, 12 - 14 November, 2013.

2 Zakaria Bahari is Lecturer of Islamic Economics and Finance, Centre for Islamic Development Management, School of Social Sciences, Unversiti Sains Malaysia.

3 Muhammad Yasir Yusuf is Lecturer of Islamic Economics, Shariah Faculty, State Institute of Islamic Studies Ar-Raniry

Aceh, Indonesia

${ }^{4}$ Emerging deals of CSR begun from the United States in the 1970s. Corporates in America gets criticism from community because it is powerful corporate and that anti-social. The spirit of corporate to eliminate competitive in business and refuse the role of law and sometimes corporate can affect the state legally for corporate interest. Hence some corporate owners recognize the impact of criticism from the community. They advice to businessmen and corporate to use their power to achieve social goals and work not only for profit. This approach produces new entrepreneurs in the business. Finally this idea is known as CSR (Frederick, et.al., 1988, 28). 
According to Corroll (1999) CSR is described to be pyramid liked, where the economic responsibility generates to corporate responsibility, followed by a responsibility to the laws, ethics and the last is charity. Dashrud (2004) concluded that there are five dimensions often used in CSR definition; these are namely environmental, social, economic, stakeholder, and charity.

There are variants existing definitions, but it can be concluded that CSR is a form of corporate commitment aimed for economic development by improving the quality of life in economy, society and the environment. In other words, CSR provides local society with active series of corporate activities as part of the effort to boost the economic welfare of the community as a whole. Some countries had established CSR in their Act as an obligation to corporations.

The concept of CSR began in the West in 1970s and discussions on the concept of CSR often revolved around the view that is founded on the norms, cultures and beliefs of the West, especially from Europe and America. Western perspective of CSR has become the core principal for corporates to run CSR programs in developing countries in general and Islamic countries in specific. However, the concept of CSR can be constructed and resourced also from the culture and norms of society such as Middle East, Southeast Asia and East Asia or beliefs, for instance Islam, Buddhism and Hinduism. Every culture, norms and beliefs of certain communities have different philosophies and epistemologies on the form and practice of CSR.

In comparison, Islamic Banking Institutions (IBIS) one of the corporation of finance is obliged to carry out CSR programs based on Islamic values, as opposed to the Western form of CSR. However, the most important thing is CSR by IBIs should be a form of accountability to Allah (SWT), humans and the environment. Therefore, CSR of IBI must be Shari'ah compliant. The IBI's, CSR programs must appropriately touch the aspect of human rights of society in order to generate a better economy and in addition the alleviation of poverty. The CSR programs should not be a mask for the pursuit more profits (The Economist, 2005) or desire of corporates to legitimize laws for the corporates' operation. (Rizk, et al., 2008: 306).

This study aims to identify the concept of CSR in Islamic perspective. The study has the following three objectives:

1. To analyse and develop CSR criteria for IBIS.

2. To analyse the customers perception of Aceh Muslim toward the IBI's CSR

3. To investigate the relationship between bank selection with perception of customers of Syariah banking in Aceh related to the practical criteria of CSR in IBIs.

The study is divided into two phases. The first phase of the study is theoretical and the method involves analysing 'contents search' from the library while the second phase is in the form of empirical research.

\section{Literature Study on The Concept of Islamic CSR}

In general, studies on CSR before mainly focused on the form of CSR in Western societies. Trend of CSR studies in the West are definitely influenced by ethical values, culture and beliefs of Western society, particularly Europe and America. Bowen (1953); Carroll (1976, 1991, 1993, and 2004); Davis (1960 and 1973); Freeman (1984); Watrick and Cohchran (1985); Wood (1991); Donaldson and Dunfee (1994); Donaldson and Preston (1995); Smith (2000); Post, Lawrence and Weber (2002); Birch and Moon (2004) are some of the figures who contributed to the studies mentioned above. They found that the values and culture that flourished in Western became the standard model of CSR.

Conventional Worldview of the concept of CSR, developed in the West, is totally different from the concept of CSR in Islam. The CSR in Islam built on the basis of tasawwur (worldview) and epistemology of Islam, which is the principle basing itself on corporate philosophy according the Al-Qur'an and Sunnah. Whereas the CSR in the West reflects the Western values and culture. Therefore, the concept of Islamic CSR requires Islamic principles and values. The concept of Islamic CSR is also considers accountability for Islamic corporates.

The concept of CSR in Islamic perspective has been conducted by some researchers such as Ekawati (2004), Mohammed (2007), Irwani and Dusuki (2007), Dusuki (2008), Zinkin and William (2010). These studies have been carried out not only to explore the concept of CSR in Islam but also to compare with conventional CSR in the UN Global Compact 5 .

Ekawati (2004) conducted a study to explore the concepts of zakat and CSR in Indonesia's. Both zakat and CSR have the same crucial goal to enhance social welfare in a society. She approves zakat as an instrument for corporates to implement CSR. Mohammed (2007) tries to explore CSR from the aspect of Islamic philosophy. He concludes that social responsibility in Islam is built on four basic principles; unity, justice, free will and responsibility. This work was an early study that laid the foundations on Islamic CSR paradigm.

5 Consists of 10 principles and four categories (human right, labor, environment and anti-corruption). 
According to Dusuki (2008) the basic concept of CSR is based on the concepts of khalifah (vicegerent) and paradigm of taqwa (piety). The concept of vicegerent denotes that mankind is the representative of Allah on earth and as such Allah has entrusted mankind with stewardship of Allah's possession. It means the corporate business works endowed by the power of Allah must be conducted in accordance with the laws of Allah. On the other side, the corporations are trying to make profit for shareholders, while also trying to maintain and develop the economic resources of society, covering issues such as good environmental practices, safety, charitable contributions, social benefits and avoidance dangerous activities $^{6}$.

The conceptual framework of Islamic CSR introduced by Mohammed (2007) and Dusuki (2008). It became the basic reference to develop further Islamic CSR models. Mohammed (2007) and Dusuki (2008) reflect a broad paradigm of Islamic business practices adherence to the principles of shari'ah. But Dusuki and Irwani (2007) include the effects of maqasid shari'ah (the objectives of Islamic law) and maslahah (public interest) in the concept of CSR. The CSR practices are divided into three categories; essentials (dharuriyyah), necessities (hajiyyah) and luxury (tahsiniyyah). These categories of maslahah can be used by corporations or management to consider the facts and situation changes when implementing CSR which can provide a better framework for managers in dealing with conflicts of interest that may arise from stakeholders (Dusuki and Irwani, 2007: 1). They have also provided details about the CSR, using the maqasid al shari'ah and maslahah. The study provides guidance to corporate managers to implement CSR according to the considerations of the three categories of maslahah.

However, these studies did not provide a framework of CSR criteria in Islam explicitly. They also did not measure how the concept of CSR was disclosed in line between concept and implementation in the field with a quantitative approach. The development of Islamic CSR criteria and its implementation may contribute to the concept and help in designing optimal policy agenda for corporations.

\section{Principles and the Underlying Concepts of Islamic CSR}

The discussion of social responsibility is frequently mentioned in the Qur'an. Al Qur'an always credited business success and economic growths to be highly influenced by ethical business practices ${ }^{7}$. Beside emphasis on the relation of moral aspect to business activities, Islam also concerned about profit in the business. Both these aspects were affirmed by the Prophet Muhammad (PBUH) (Malik, 795, 2:980)8. This hadith concludes that minimum wages should allow a worker or employee to obtain good food and feasible clothing, reasonable amount for himself and his family without having to work hard (Yusuf, 2008: 151).

Environmental sustainability is one of the social responsibilities of each human and business corporation. Responsibility to environment was mentioned in al Qur'an in Chapter al-Baqarah, 2: 2059: This verse describes how Islam considers environmental sustainability. All the activities of business or non-business should ensure environmental sustainability. Islam has clearly prohibited anything that is harmful to individual or hazardous environmentally to maintain a harmony relationship between human being and environment. In essence, this obligation required human being to care for the constant well being of society and to safeguard enviroment for the sake of next generation.

In terms of social welfare, Islam encourages generous Islamic charity for those in need through sadaqa $h^{10}$ and welfare loans (Qard hasan) ${ }^{11}$. Allah mentioned it in Al Quran, (Chapter al Taghabun, 64: 16) that the responsibility of

${ }^{6}$ Paradigm of taqwa (piety) means a person is imbued with a strong understanding that their role in this world is to manage and develop the world in accordance with the shari'ah. This means harmonizing and integrating material well-being with moral-spiritual values, which in turn determines their fate in this world and in the hereafter. It provides a number of values for shaping social life and clarifies the status of human beings and their position in relation to the rest of creation. Furthermore, it defines the nature of human beings' relationship with Allah, with each other and with the natural environment (Dusuki, 2008: 15-17). This will produce a godly paradigm concept of CSR practices that focus on maintaining human dignity, freedom of work, justice and recognition of individual rights, beliefs and responsibilities.

7 "Give full measure when ye measure, and weigh with a balance that is straight: that is the most fitting and the most advantageous in the final determination" (al Isra, 17: 35)

8 "A worker/employee is entitled to at least get good food and clothing with a decent size and is not burdened with ability to work outside the limits. (Malik, 795, 2: 980) - hadist narrated by Malik ibn Anas

9 "And when he turns his back, His aim everywhere is to spread mischief through the earth and destroy crops and cattle. But Allah loved not mischief"(Chapter 2:205)

10 In Islam, the word has two meanings sadaqah. Sadaqah first significant donation to charity, and required that both voluntary donations as charitable contributions. 
Muslim is to help others throughout charitable contributions and donations and stinginess is abomination in Islam ${ }^{12}$. Benevolent loan (Qard hasan) can also bring double benefits for individuals and corporations. It can create a positive image for individuals and corporations as well as getting a new business network formation, which may result in increase in profits. In terms of sadaqah, The Prophet Muhammad (PBUH) said in a hadith narrated by Salman bin Amir, "Alms for the poor is charity. And the charity to family has two advantages, namely the rewarding for Allah and strengthening brotherhood" (Narrated by Tirmidhi, 1993: Hadith No. 653). Both Al Quran and hadith mentioned above demonstrate the concept of social responsibility and justice has long existed in Islam.

Even though the verses of Qur'an and the hadith do not directly point out to CSR but there are numerous verses in the Qur'an and hadith which explain the obligations of individuals to bear the needs of others. Hence for individuals that come together to create a corporate have the obligations to help the public and give benefits to others. The existence of corporation were viewed by jurists such as Shafi'i, Ahmad bin Hambal, Ibn Hamid al-Ghazali, Ibn al-Faraj, Ibn Al Jawzi which occupied a position as fard kifaya ${ }^{13}$. Corporations can do what individual find hard to do, corporation can bear and take care the interests of the larger community, such as foundation (Ibn Taymiyya, 1314H).

In fact CSR corporate not only bears and cares for living creatures around them, but more than that, CSR is the obligation of humans to comply with Allah's laws. Allah has commanded humans to obey Him, and a form of obedience to Allah is to ensure the survival of human kind and the natural surroundings (Chapter al Dzaariyat, 51; 56) ${ }^{14}$. The existence of Muslim on earth is to accomplish two tasks; first, to be an obedient servant to Allah and second is to become the fair caliph $^{15}$. The relationships between the two main tasks are in line and should not be separated from one another. Each individual has an obligation to make all events of his life as a form of perfect devotion to Allah. In this case, the concept of worship is necessary to be understood in a broader sense. This means that apart from the specific worship of ritual of piety, each individual is required to perform other common rituals of all the activities that bring about the welfare of man and nature in compliance with certain conditions, with right intentions and have to ensure that those actions allowed in the shari'ah (Suhaila binti Abdullah, 2008: 64-68, Zahari bin Mahad Moses, 2008: 77-78, Abdullah al Mushlih and Shalah al Shawiy, 1998: 161). As a vicegerent, humans are entrusted to manage this environment which involves relationship among human beings and relationships with other Allah's creations, including animals, plants and the environment. Al Mawdudi interpreted meaning of the word "vicegerent" as "representative of Allah on earth" (Abu al-A'la al Maududi, n.d:16-23). This supported by Ibn Kathir and he explains humans purpose of ruling the earth (khalaif al Ard) in verse 6; 165 ; is as executors for the prosperity of the earth from time to time to be utilized by future generations (Ibn Kathir, 1996: 185). As the vicegerent of Allah on earth humans do not have absolute freedom to do whatever they want. Mankind must act within the authority delegated to him by Allah ${ }^{16}$.

Both interpretations quoted by al Maududi and Ibn Kathir about the meaning of vicegerent, gives a clear picture of the duty of every human being to be responsible to Allah as the Giver. Accountability as representative of Allah requires that people take care of nature and all its contents for the salvation of man himself and the survival of other creatures of Allah. Individuals are entrusted to guard themselves and escort from the various forms of fraud.

Therefore, based on the discussions above the position of CSR in Islam is one of the essential human tasks which are a mandate from Allah. On one hand CSR is the obedience to Allah, on the other hand it serves as a human responsibility as the vicegerent of Allah on earth. Therefore, those who were bestowed with talents or power and high position by Allah are obliged to help other humans in order to ease the burden on those who face poverty and disability.

\footnotetext{
${ }_{11}$ Qard Hasan is good credit to whom, who do not take advantage. Total amount of loan repayment is accordance with the loaned property.

12In the Al Qu'ran, Allah mentions in at least 64 section, which describes an important donation to charity. As of 2:43, 83, 110, 177, 215, 263, 264, 270, 271, 273, 274, 276, 277, 280, 4:77, 114, 162, 5:12, 45, 55, 7: 156, and others.

${ }^{13}$ Fard kifayah mean anythings societies are obliged to possess, though the task of acquiring them may be left to certain individuals or groups. Implicit in the meaning of this category of knowledge or obligation is that without it a society would lack something that is important to its well-being.

14 "I have only created Jinns and men, that they may serve Me." (Chapter al Dzaariyat, 51; 56)
}

\footnotetext{
15 "It is He who hath made you (His) agents, inheritors of the earth: He hath raised you in ranks, some above others: that He may try you in the gifts He hath given you: for thy Lord is quick in punishment: yet He is indeed Oft-forgiving, Most Mercifu"l. (Chapter al An'am, 6: 165).

16 "O David! We did indeed make thee a vicegerent on earth: so judge thou between men in truth (and justice): Nor follow thou the lusts (of thy heart), for they will mislead thee from the Path of Allah: for those who wander astray from the Path of Allah, is a Penalty Grievous, for that they forget the Day of Account". (Chapter Shaad, 38; 26).
} 
Hence, Islamic CSR obligations are the responsibility of individuals who come together in one corporate to give a positive impact for the environment in order to empower the weak and to preserve natural surroundings. The abandonment of CSR obligations may cause the anger of Allah and incur punishment. In contrast implementing CSR will give birth to pleasure and comfort in formation of cooperative and intimate relationships between the corporate and community ${ }^{17}$.

CSR activities in Islam have clear demarcations between permitted and forbidden which are fixed indicators determined by shari'ah. CSR activities cannot change permitted (halal) to forbidden (haram) or vice versa. From another side, the accountability of hereafter arises from an understanding of taqwa to produce different values in the implementation of CSR. Islamic CSR has is based on the philosophy of Al Qur'an and al Sunnah as it provides guidance about various activities regarding life, including CSR practices. Islamic CSR must be understood as part of shari'ah compliance. Islamic CSR is to be practiced in line with the principles of al Qur'an and al Sunnah and not just merely fulfil al kifayah (obligatory upon community) and giving a positive image to corporate, but also as a method to alleviate poverty.

Principles of CSR in the Islamic perspectives from previous studies can be reviewed and summarized as below:

Table 1: Principles of CSR Practices from the Islamic Perspective

\begin{tabular}{|c|c|c|}
\hline Researchers & $\begin{array}{l}\text { Islamic Principles of CSR in } \\
\text { Practices }\end{array}$ & Research Objectives \\
\hline Ekawati (2004) & 1. Zakat as an instrument of CSR & $\begin{array}{l}\text { To explore the relationship between zakat, } \\
\text { CSR and community development at Bank } \\
\text { Muamalat Indonesia }\end{array}$ \\
\hline Mohammad (2007) & $\begin{array}{l}\text { 1. Unity of Allah } \\
\text { 2. Justice } \\
\text { 3. Free will } \\
\text { 4. Responsiblity }\end{array}$ & $\begin{array}{l}\text { To expose the Islamic paradigm of CSR and } \\
\text { compare with conventional CSR. The study } \\
\text { also looks at how the values of CSR practiced } \\
\text { by Islamic banks using in depth interviews } \\
\text { with managers of Islamic bank. }\end{array}$ \\
\hline Dusuki (2008) & $\begin{array}{ll}\text { 1. } & \text { Caliphate } \\
\text { 2. } & \text { Taqwa (Piety) }\end{array}$ & $\begin{array}{l}\text { To review and produce the concept of CSR in } \\
\text { Islam and compare with CSR in the west. }\end{array}$ \\
\hline $\begin{array}{l}\text { Dusuki dan Irwani } \\
\text { (2007) }\end{array}$ & $\begin{array}{l}\text { The practice of CSR is divided into } \\
\text { three categories: } \\
\text { 1. Emergency (essentials) } \\
\text { 2. Interest (necessary) } \\
\text { 3. Luxury (embellishment) }\end{array}$ & $\begin{array}{l}\text { To provide guidance for corporate managers } \\
\text { to implement the CSR programs in } \\
\text { consideration of maqasid shari'ah and } \\
\text { maslahah. }\end{array}$ \\
\hline
\end{tabular}

Source: Ekawati (2004), Mohammed (2007), Dusuki (2008), and Irwani Dusuki (2007)

The principles that have been discussed in the previous studies can be concluded by three principles of Islamic CSR. The principle of unity (Mohammed, 2007), the principle of Justice (Mohammed, 2007), the principle of Caliphate (Dusuki, 2008). The zakah can be used in the CSR practice Ekawati (2005). However, zakah is not one of the CSR principles. While the concept of free will and responsibility as state by Mohammed (2007) and taqwa mentioned by Dusuki (2008) were the effects that arise when the principles of unity, justice and the caliphate were applied they are not principles which can stand alone.

Principle is defined as base, initial, basic rules (Suryadi, 1980: 190). According to Juhaya (1995: 69), principle is the beginning that is the point of departure (al-mabda). Principle is a universal truth that naturally exists in Islamic law

17 "It is He who hath made you (His) agents, inheritors of the earth: He hath raised you in ranks, some above others: that He may try you in the gifts He hath given you: for thy Lord is quick in punishment: yet He is indeed Oft-forgiving, Most Mercifu"l. (Chapter al An'am, 6: 165) 
and the starting point of its construction. It is a basic legal form and produces all branches (Juhaya, 1995). It can be concluded that a base or fundamental is used as the basis for the foundation of work practices.

The position of the implementation of Islamic CSR can be categorized into three dimensions. Firstly, it is the relationship of responsibility to Allah. Secondly, the relationship of responsibility to humanbeing. And the last is the relationship of responsibility towards the environment.

To realize the three links at Islamic CSR practice on IBIs, it require the principles that are inter-related to each other, that is the principle of unity of Allah, caliphate, justice, brotherhood, and creation maslahah (public benefit). The implementation of Islamic CSR principles in the IBIs and the positions of the responsibilities based on three relationships that must be played by a Muslim can be described in the following Figure 1:

Figure 1: The implementation of Islamic CSR principles to IBIS

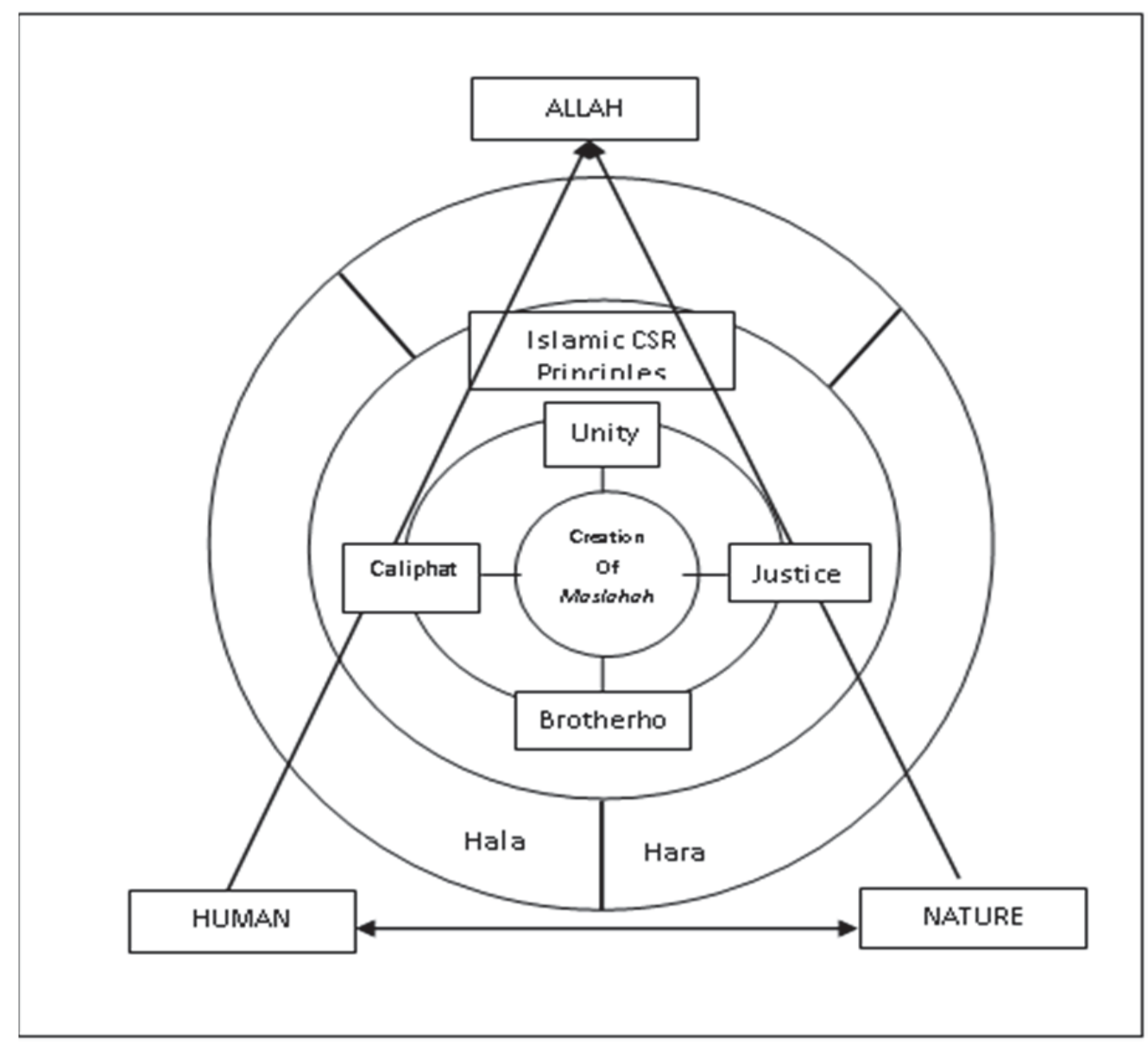

Figure 1 explains that the implementation of CSR is the manifestation of three strong relationships that intertwined among each other; relationship with Allah, human relationships and relationship with nature. To optimize these three relations in the implementation of CSR, it must be guided by the principles of unity of Allah, caliph, justice, solidarity. The four principles are aimed at realizing the end of the fifth principle which is the creation of maslahah (public benefit) for humans and the nature. Creating maslahah in IBIs is a key goal in implementing all the functions of Islamic banking transactions included in the implementation of Islamic CSR. All implementation of CSR in Islamic banking transactions should be guided by halal outlined by Islam and abandon any prohibition as prevented in Islam. All of these principles are practiced with the sole purpose of perfect devotion to Allah SWT. 
Implementation of Islamic CSR principles in IBIs, based on Qur'an and Sunnah in the whole Islamic banking activities, will be a vehicle to drive the economy in a right direction.

\section{Criteria and Instruments of CSR in Islamic Banking Institutions (IBIs)}

The criteria which have been studied by researchers are assembled in a conceptual framework. This conceptual framework can be used as the standard in the implementation of CSR in IBIs. In general, social responsibility in Islam can be categorized into three forms of relationship responsibilities. Firstly, it is the relationship of responsibility to Allah. Secondly, the relationship of responsibility to human beings. And the last is the relationship of responsibility towards the environment. To realize the three links at Islamic CSR practice on IBI, require the five principles that are inter-related to each other, that is; the principle of unity of Allah, caliph, justice, brotherhood, and creation maslahah (public benefit).

From the five principles six criteria can be obtained and 34 items as instruments to measure corporate social responsibility in the IBIs. Six criteria's of CSR in IBIs come out from deep reading of numerous literatures and understanding from Qur'an and hadith namely, (1) Shari'ah compliance; (2) equality, (3) responsible attitude; (4) guarantee of welfare; (5) guarantee of environmental sustainability and (6) charity for preservation of virtue.

The 34 items that can be instruments measuring these criteria are:

First, the criteria of Shari'ah compliance have five items: (1) Instruments IBI compliance with shariah; (2) Financing IBI compliance with shari'ah; (3) IBI's investment in halal products; (4) Avoiding profit from non-halal; (5) Selections of customer according to shari'ah

The Syari'ah compliance criteria and five items to measure those criteria are based on the interest to keep all IBIs' products and investment lawful as outlined by the Qur'an. There are many verses describing these obligations, Allah says in verses al-Mu'minun: 51; al-Baqarah: 188, 275, 278, 279, and al-Nisa': 10.

The prophet Muhammad PBUH said in hadith:

"Searchin the halal is obligatory on every Muslim." (Narrated by Ibnu Mas'ud).

In banking and finance, all forms of transactions are possible, unless there is any clear evidence or injunction banning a transaction. Therefore each transaction in IBI must be based on shari'ah in instruments, financing schemes, investment and customer selection.

Second, the criteria of equality has four items; (1) The existence values of brotherhood; (2) Excellent services; (3) Avoid discrimination and (4) Have the same opportunity

Equality in life has been described in the Qur'an, in chapter Ali 'Imran, 3: 103, al-Anfal: 62-63, al Mukminun; 23:8, al Hujurat; 49:13. The verses explain that the people living in various communities have the duty to respect and cultivate the values of brotherhood with human being in various activities.

The prophet Muhammad (PBUH) said in varieous hadith:

"The glory of a believer is because religion, dignity is at the intellect and position is dependent on ethic" (Narrated Baihaqi).

"Allah loves when you do a job to work correctly and properly" (Narrated by Baihaqi).

Third, the criteria of responsible in work has eight items; (1) Trust, (2) Working accordance with the limitations and responsibilities, (3) Fulfill every contract demand; (4) Transparency; (5) Optimal for using time and expertise; (6) Reducing the adverse impact of the investment; (7) Integrity in the work; (8) Fair competition and (9) Accountability.

Responsibility in work is something very important in the Muslim life. Every employee must show responsible attitude not only to his/her employer but more than that to Allah also. He will be asked in the Hereafter of what he had done in the world. Obligation to be responsible in their jobs have described at numerous verses in the Holy Qur'an in Surah al Maidah, 5:2, al Munafikun, 63:9, Al Baqarah, 2: 237, Al Baqarah, 2: 195, al Qashash: 77, al Nahl, 16:97. While in sunnah, Muhammad (PBUH) said;

\footnotetext{
"Muslim traders who are true and trusted in trading are with the martyrs on the Day of Judgment" (Narrated by Ibnu Majah dan Tirmizi).

"Jabir bin Abdullah said that the Rasulullah PBUH said; Allah loves to his servants who acts politely and considerately when selling, buying or reclaiming debts." (Narrated by Ibnu Majah) 
Fourth, the criteria of guarante of welfare has six items; (1) place of work; safe and comfortable, (2) Free will, (3) Eligible of Wages ; (4) Training and Education; (5) Work does not exceed the limits and time; (6) Profit and loss sharing; (7) Insurance for employee.

Islam is very concerned in giving guarantee of welfare for the people who are involved in every jobs. The relationship between employers and workers, staff and manager must have regulation with the norms of compulsory specific guidelines for creating both sides fairly and qualified. This is the order of Allah in the Qur'an, as mentioned in Surah al-Nahl 16: 90. The Prophet Muhammad (PBUH) also said:

"A worker / employee is entitled to at least get food, proper clothes and not be burdened with the job beyond his ability "(Narrated by Malik, n.d: 2:980).

"It is not a Muslim who was sleeping in a gorged while his neighbour is in conditions of hunger" (Narrated by Bukhari).

Fifth, the criteria of guarantee of environmental sustainability has four items: (1) To ensure that investment does not harm the environment, (2) Involve actively in protecting the environment, (3) Educating employees about environment threats (4) The used of recycled materials to fulfill needs of the IBIs.

The relationship between humans with nature is very close and cannot be separated. Interaction with nature is part of evidencing the greatness of Allah for making the universe to support human being. Allah describes this at the Qur'an in chapter Rum, 30: 41. al Baqarah, 2: 204-206 and al-A `raf 7: 56.

Sixth, the criteria of charity for preservation of virtue has five items;(1) The selection of investors to support the activities for social welfare, (2) Alleviate social problems (such as opening the welfare funds and donations) (3) Support and help fund welfare (such as helping to fund education, social donations, and ease the life of orphan) (4) Playing the role of welfare without looking solely for profitability, and (5) The empowerment of communities through IBIs products (such as Qard hasan, financing micro-economics to poor families and small businesses).

Islam highly recommends humans to give welfare assistance to anyone in need and who are unable to work. The Qur'an explains a lot about this. Among them are found in chapter al Nahl, 16:71 and 75, al Maidah, 5; 2, Al Taubah, 9; 71. In addition, Prophet Muhammad (PBUH) said:

"Anyone who doesn't love mankind, it's not loved by Allah" (Narrated by Bukhari, Muslim).

"Abu Huraira said, Rasulullah has said: Those who seek to help widows and the poor are similar in rank to those who fight in Allah, pray at night and fasting during the day" (Narrated by Bukhari).

Islamic criteria of CSR in IBIs can be related with stakeholders and CSR principles of Islam can be shown in table 2 below:

Table 2: Criteria, Item and Relationship with Stakeholder and Principle of Islamic CSR

\begin{tabular}{|c|c|c|c|c|c|}
\hline & Criteria & & Item & Islamic Banking Stakeholders & Islamic CSR Principle \\
\hline & \multirow[t]{5}{*}{$\begin{array}{l}\text { Shari'ah } \\
\text { compliance }\end{array}$} & & $\begin{array}{l}\text { Instruments IBIs compliance } \\
\text { with shari'ah }\end{array}$ & Worker and shareholders & Unity \\
\hline & & 2. & $\begin{array}{l}\text { Financing IBIs compliance } \\
\text { with shari'ah }\end{array}$ & $\begin{array}{l}\text { Shareholders, worker and } \\
\text { customers }\end{array}$ & Unity, caliphate and justice \\
\hline & & & $\begin{array}{l}\text { IBI's investment in halal } \\
\text { products }\end{array}$ & $\begin{array}{l}\text { Shareholders, workers and } \\
\text { customers }\end{array}$ & Unity, caliphate and justice \\
\hline & & & $\begin{array}{l}\text { Avoiding profit from non-halal } \\
\text { products and services }\end{array}$ & Workers and Shareholders & Unity and caliphate \\
\hline & & & $\begin{array}{l}\text { Selection of customer } \\
\text { according to shari'ah }\end{array}$ & $\begin{array}{l}\text { Shareholder, worker and } \\
\text { customer }\end{array}$ & Unity, caliphate and justice \\
\hline \multirow{3}{*}{\multicolumn{2}{|c|}{ 2. Equality }} & & $\begin{array}{l}\text { The existence values of } \\
\text { brotherhood }\end{array}$ & $\begin{array}{l}\text { Shareholder, worker, } \\
\text { community, customer }\end{array}$ & Brotherhood, justice \\
\hline & & & Services excellent & $\begin{array}{l}\text { Shareholder, worker, } \\
\text { community, customer }\end{array}$ & Brotherhood, justice \\
\hline & & 3. & Avoid discrimination & Shareholder, worker, & Justice \\
\hline
\end{tabular}




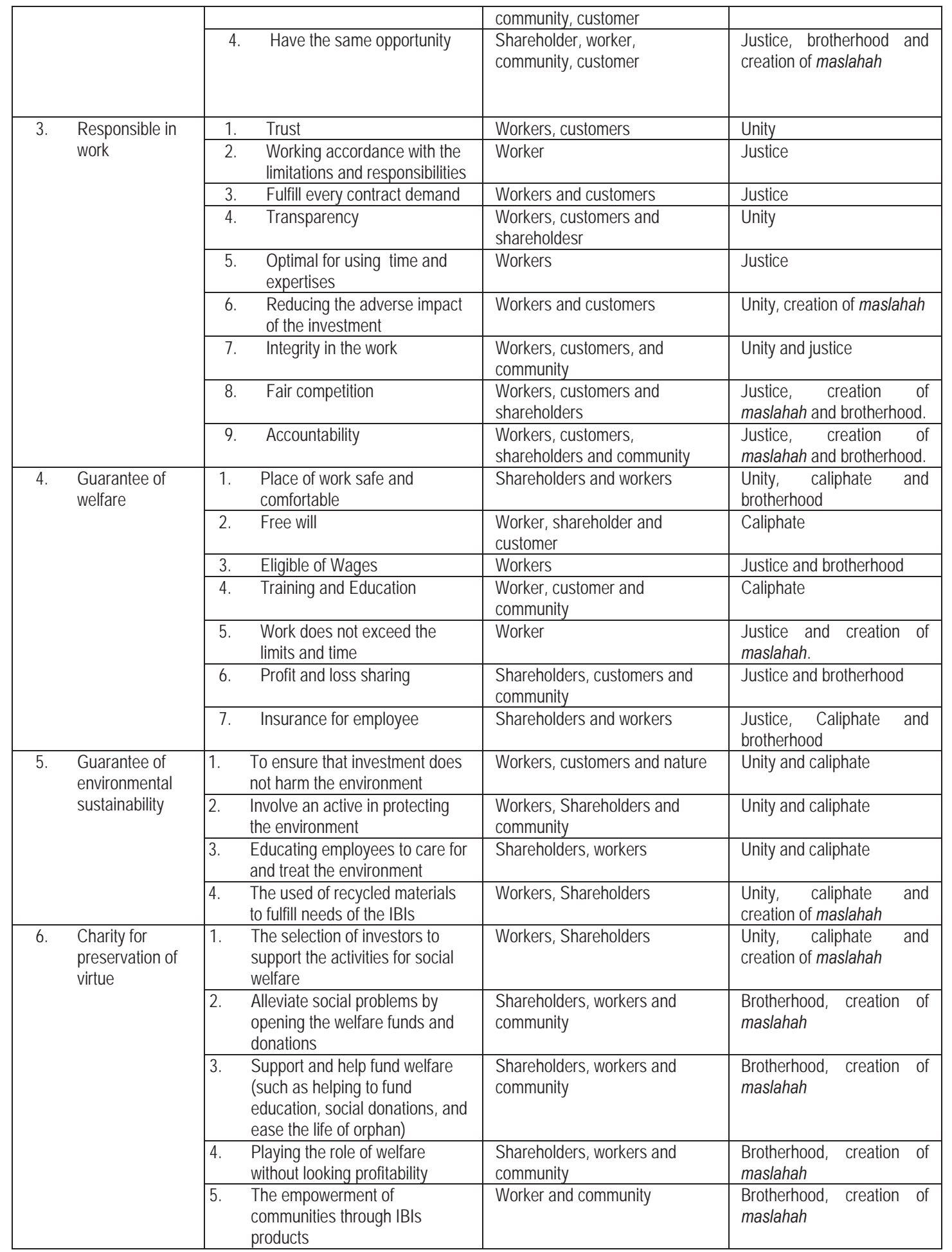


Table 2 above reflects the relationship between the criteria of CSR, stakeholders IBIs with Islamic principles of CSR. It is a network that can not be separated from one another. Each criteria has an impact on the stakeholders; and each criteria is based on the principles derived from al Qur'an and al Sunnah.

The description on the criteria and items to be included as Islamic CSR instruments can be used as the conceptual framework for the implementation of CSR in IBI (see Figure 2). The conceptual framework can be described as a series of IBIs activities in performing all banking transactions with appropriate responsibility to Allah, human being and in ensuring environment sustainability. This three dimensions of responsibilities are to be implemented with the fourth principles which are unity, caliphate, justice and brotherhood. And fourth principle is intended to create the fifth principle which is the creation of maslahah to humans and the environment.

The creation of maslahah is the main purpose of the $\mid \mathrm{BI}$ in performing of all the functions of banking transactions. While the six criteria for CSR at IBI is to ensure that operational IBI occupies the terms and implement syari'ah correctly. Thus, the objective of IBIs to provide greater social impact within the environment can be achieved (IAIB 1990, Wahbah Zuhaili, 2003, Sudin Haron, 2005).

The conceptual framework in the implementation Islamic CSR in IBI described above can be seen in figure 2:

\section{Figure 2: The conceptual Framework:Implementation of Islamic CSR in IBI}

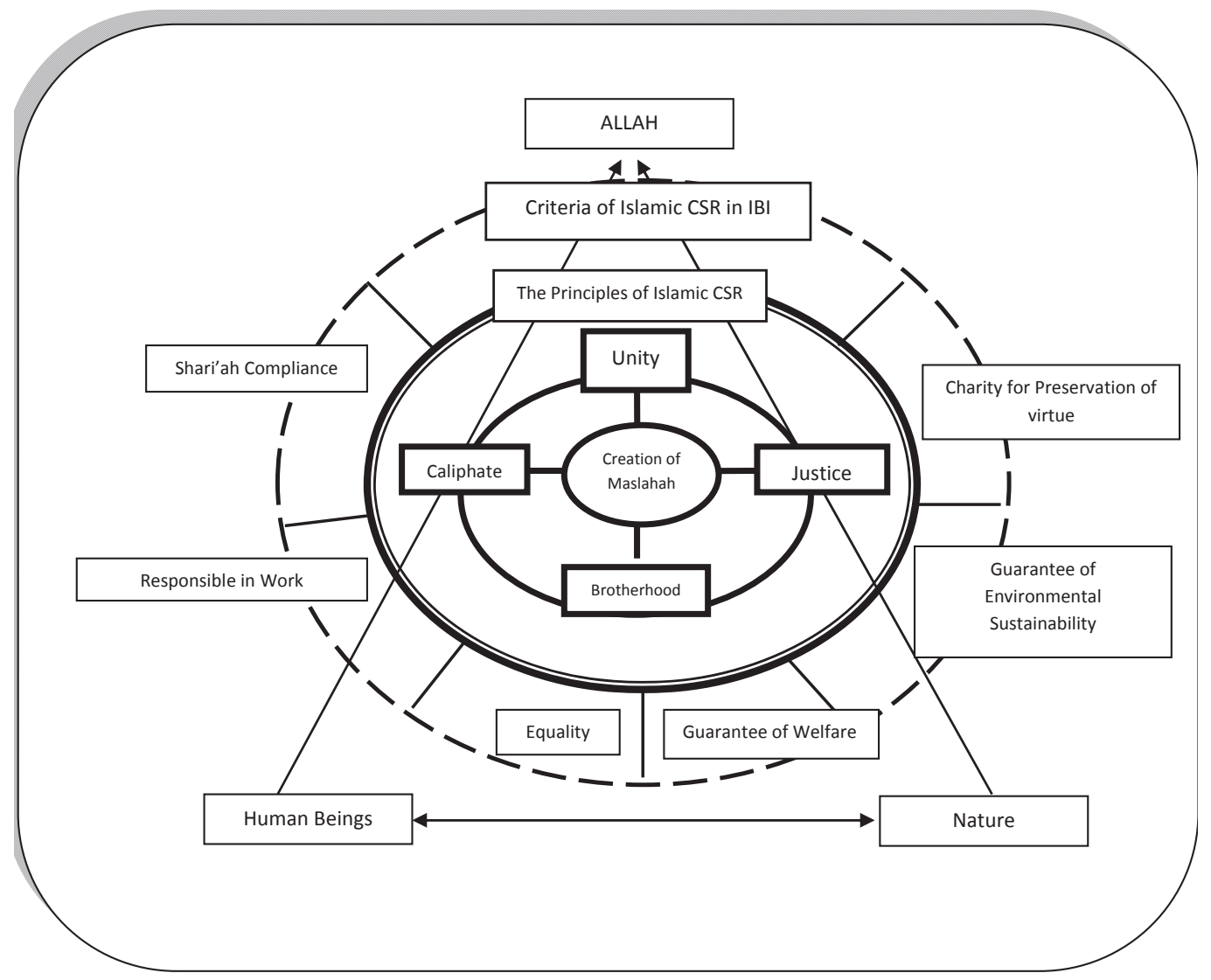

\section{Research Method and The Instrument of Survey}

The second purpose of this study was to to analysis the customers perception of the Islamic Banking was in Aceh to CSR and to assess the relationship between bank selection with perception of customers Syari'ah banking in Aceh about 
practical criteria CSR of IBIs. To achieve the this purpose, survey was done on 400 costumers of IBIs in Aceh to gather views and their perceptions of CSR at IBIs in Aceh.

To minimize the bias element that can emerge from this survey used a structured questionnaire with a few closed questions carefully constructed. Questionnaire using several scales of measurement, nominal scale, ordinal and interval used to determine demographic and background information of customers such as gender, age, education level and income.

To measure customers' perceptions, Likert scale was used to be suitable. Scale scores seen answer to give more focused, clear and facilitate the customers to answer the questions posed (Zikmund, 2000: 300). Given the scale of 1 to 6 to reflect customers' views on whether a statement "strongly disagree", "disagree", "do not agree", "somewhat agree", "agree" and "strongly agree".

Scale 6 is a progressive scale of nature. It is used for two reasons. First, the customers are those who are directly involved with the subject of study. The subjects of the study which become samples were users IBIs. Therefore subject of study trying to provide feedback a positive or negative against questions are lodged and there is no reason for them to be neutral. On that basis, there is no option tobe neutral given in the scale answer. Second, the use of the scale of 6 a score of this is to avoid customers of continue to be neutral if given options 'uncertain' in the scale answer. So by using a scale 6 score this, he can verify the answer of customers reached mean research. The high scores reflect positive perceptions and support, while inferior score reflect negative perception and not support (Anderson. Et.al, 1983:253).

The stage of the perception on practice of CSR IBIs measured by using a scale 6 score, namely the score 1 strongly disagree so as to score 6- strongly agree. The categorization the level of perception of a questionnaire is based on the value of the score at least namely the score at least among 1.00 until 2.60 please is considered low. Score min between 2.61 to 4.20 is also considered a simple and score min 4.21 until 6.00 is considered high. It is as expressed by Husein Umar (2005).

The content of the questionnaire was designed based on criteria and IBIS CSR items that have been first get confirmation of two experts who found as customers to give legality 18 to a questionnaire so as to achieve the purpose and objective research. Before the final draft of the questionnaire form is mailed to the true customers, path study conducted to test a questionnaire so worthy of and deserving of instruments. Based on the answers of the customers in path research some modifications made to modify a questionnaire before passing research actually on the participants who became a sample.

\section{Research Method and The Instrument of Survey}

As discussed at the begining, that the methodogoloy of the study is divided into two parts. The first part was consist of conceptual development of CSR in Islamic context while this part is consit of emperical evidences about people perception about Islamic CSR. This portion invesitages what are the perceptions of Muslim customers about CSR, in Aceh about the Islamic Banking institutions? Moreover, the study assesses the differential in perception of Muslim customer in Aceh toward CSR criteria in Islamic Banking. To achieve this purpose, a survey was conducted to collect information about these aspects from 400 Muslim costumers to invesitigate their views and perceptions of CSR toward IBIs in Aceh. The questionnaire using several scales of measurement such as nominal scale, ordinal and interval scale to determine demographic and background information of customers such as gender, age, education level, income etc., that has been confirmed by two experts to give legality ${ }^{19}$ to a questionnaire so as to achieve the purpose and objective research.

To measure customers' perceptions, Likert scale was used. Scale scores answers more focused, clear and facilitate the customers to answer the questions (Zikmund, 2000: 300). Given the scale of 1 to 6 to reflect customers' views on whether a statement "strongly disagree", "disagree", "do not agree", "somewhat agree", "agree" and "strongly agree". The high scores reflect positive perceptions and support, while lower score reflects negative perception and no support (Anderson. Et.al, 1983:253). The categorization the level of perception of a questionnaire is based on the value of

${ }_{18}$ Substance validity is known with content validity which doing by a group of expert who is researching the scale and agree that the items which contain in the scale may delegate items which is related with the draft will be measured. This page like is proven by Sabitha.

${ }^{19}$ Substance validity is known with content validity which doing by a group of expert who is researching the scale and agree that the items which contain in the scale may delegate items which is related with the draft will be measured. This page like is proven by Sabitha. 
the score at least namely the score is between 1.00 until 2.60 . Minimum score is between 2.61 to 4.20 is considered a simple and score min 4.21 until 6.00 is considered high (Husein Umar, 2005).

\section{Data Collection}

The study was conducted in June and July 2011. The specific criteria customer IBIs in Aceh who became a sample of study is; customer who has usual used one of facilities IBIs, customers who are Muslim and the last who settled in Aceh. Mmethod of experiments used is convenience of sampling to select customers IBIs ${ }^{20}$. Customers IBIs that satisfy characteristics as a participant who came to visit IBIs selected when time $09.30 \mathrm{am}$ until $04.00 \mathrm{am}$ set as random customers. There were 16 (sixteen) IBIs in four regions / cities across while we selected three zones for survey. Zone 1: Banda Aceh (9 IBIs); Zone 2: Greater Aceh (2 IBI) and Zone 3: Lhoukseumawe / North Aceh (5 IBIs). All banking institutions available in zone 4 (four) cities and districts in Aceh, which is the highest has banking offices of IBls in 3 (three) zones

\section{Analysis of Muslim Customers Perceptions}

\section{Customers' Profile}

Profile of the customers shows information about the customers' sex, age, level of education, marital status, jobs and average monthly income. The details are shown in the Table 3.

Table 3: Customers Profile of IBIs $(\mathrm{N}=400)$

\begin{tabular}{|l|c|c|}
\hline \multicolumn{1}{|c|}{ Profile } & Frequency & Percentage (\%) \\
\hline Gender & & \\
Male & 194 & 48.5 \\
Woman & 206 & 51.5 \\
Total & 400 & 100.0 \\
Age & & \\
$6-20$ year & 26 & 6.5 \\
$21-30$ year & 218 & 54.5 \\
$31-40$ year & 107 & 26.8 \\
$41-50$ year & 37 & 9.3 \\
50 Years old and upward & 12 & 3.0 \\
Total & 400 & 100.0 \\
Marital status & & 42.3 \\
Unmarried & 169 & 54.8 \\
Maried & 219 & 3.0 \\
Widower /widow & 12 & 100.0 \\
Total & 400 & 0.5 \\
The highest stage of education & & 0.8 \\
Eelementary school & 2 & 21.0 \\
Juniors high school (SMP) & 3 & 17.5 \\
Senior high school (SMA) & 84 & 51.5 \\
Diploma & 70 & 8.2 \\
The young scholars & 206 & 0.5 \\
Sscholar & 33 & 100.0 \\
Doctors (PhD) & 2 & 5.0 \\
Ttotal & 400 & 18.2 \\
Job Status & & \\
unemployed & 20 & \\
student/university student & 73 & \\
\hline
\end{tabular}

20 The selection method was based on two reasons. First, the list and the number of users of the bank is something that is rather difficult obtained from the institutions that can give trouble for getting a framework sampling (Khan et al., 2007). Second, a number of bank user is something difficult so very difficult for getting the right number of population. 


\begin{tabular}{|l|c|c|}
\hline Private employees & 80 & 20.0 \\
An accomplice kingdom & 121 & 30.3 \\
Institutions not kingdom & 3 & 0.8 \\
State-owned / regional & & 1.2 \\
(BUMN/BUMD) & 5 & 17.0 \\
Entrepreneur & 68 & 7.5 \\
Others & 30 & 100.0 \\
Total & 400 & 28.8 \\
\hline \hline Average of Monthly Income & & 46.8 \\
O to 1 million'1 & 115 & 15.2 \\
More than 1 million until 3 million & 187 & 5.5 \\
More than 3 million until 5 million & 61 & 2.2 \\
More than 5 million until 7 million & 22 & 1.5 \\
More than 7 million to 9 million & 9 & 100.0 \\
More than 9 million & 6 & \\
Total & 400 & \\
\hline
\end{tabular}

Table 5 shows that the users are not dominated by any gender for example male customers are 48.5 percent while, women customers are 52.0 percent. Age of the customers also indicates multiplicity rank, starting from those aged 16 to 20 years (8\%). Majority of customers were aged between 21 and 30 years (54.5\%). The customers were predominantly by married group (54.8\%) while unmarried customers were consist of 42.3 . the customers were also dominated by those who got young scholars diploma (51.5). An average monthly income of customers was dominated by those with income of more than 1 million to 3 million (46.8\%). This is because most customers are from private kingdoms and accomplices. While customers whose income ranges from 0 to 1 million are 28.8 percent. The customers who have income over 3 million to 5 million are 15.2 percent, who work as entrepreneurs. This phenomenon become parallel with the Aceh Government legislation that Provincial Minimum Wage (PMW) of Aceh in 2010 is Rp 1,300,000 per month.

\section{The Level of Perception Customers IBIs to CSR IBIs}

The level of the perception about the practice of CSR by IBIs were measured through the minimum amount obtained based on six primary criteria; syari'ah compliance, equality, responsible in work, guarantee of welfare, guarantee of enviromental sustanaibility and charity for preservation of virtue. All these six criteria were used to assess the perception among customers. If formulated simple of any criteria CSR, IBIs, the average minimum of all criteria practice of CSR, IBIS from users show that the perceptions of the users are at a very high level. The minimum score ranges from 4.21 to 6.00 is considered high. This means that Muslim customers in Aceh have good perceptions to CSR, IBIs. This can be shown in Table 6 below:

Table 4: Formulation of the Entire Minimum Average of various Criteria CSR IBIs of Customers

\begin{tabular}{|c|l|c|c|}
\hline No & \multicolumn{1}{|c|}{ Criteria } & Minimum & Interpretation \\
\hline 1. & Shariah Compliance ( CS ) & 4.62 & High \\
\hline 2. & Equality (E) & 4.86 & High \\
\hline 3. & Responsibility in work (RW) & 4.39 & High \\
\hline 4. & Guarantee of Welfare (GW) & 4.83 & High \\
\hline 5. & Guarantee of Environmental Sustainaibility (GES) & 4.21 & High \\
\hline 6. & Charity for Preservation of Virtue (CPV) & 4.78 & \\
\hline
\end{tabular}

The above table shows high perceptions of the customers regarding different items CSR using by IBIs. The detail of the items are; Criteria syariah compliance $(M=4.62)$, criteria equality $(M=4.86)$, criteria responsible in working $(M=4.39)$, criteria guarantee of welfare $(M=4.83)$, criteria guarantee of environmental sustainaibility $(M=4.21)$ and charity for preservation of virtue $(\mathrm{M}=4.78)$.

211 million Rupiah is equal to exchange Rs 349, (www.bnm.gov.my / statistics / exchangerates.php) on September 11, 2011 retrieved date. 
However, natural conservation security is criteria having an average minimum lowest among 5 the other criteria. It is because some customers did not get confidence about IBIs in Aceh in giving any actions of natural conservation. Lack of focus on criteria guarantee of environmental sustainaibility can be proven by some other customers somewhat agrees that IBIs do not concern with environmental sustainability $(M=3.93)$. The rate of less agree of customers is on a statement that there is no assistance funds from IBIs that was given to maintain and preserve environment $(M=3.37)$ of active item in protecting the environment. Perceived level between 2.61 minimum score until 4:20 showed moderate level.

Therefore, IBIs in Aceh has to take more attention in keeping and caring for nature in various IBIs activities. If the stage of customers perceptions are formulated regarding the work of CSR, IBIs in Aceh, the form of questionnaire items proposed in ranking, so it can be formulated as follows:

Table 5: Questionnaire Items that Occupy the Highest Ratings from the Customers based on the min value:

\begin{tabular}{|c|c|c|}
\hline No & Customers & Min \\
\hline \multicolumn{3}{|c|}{ The Syariah Compliance Criteria } \\
\hline 1 & Sharia banking does implement on halal services and products. & 5.04 \\
\hline 2 & Saving product/deposit of Sharia banking is managed in accordance with the rules of Sharia. & 4.99 \\
\hline 3 & Sharia banking avoids the profit that is acquired not legally. & 4.99 \\
\hline \multicolumn{3}{|c|}{ Equality Criteria } \\
\hline 1 & Sharia banking employees respect me as a customer & 5.00 \\
\hline 2 & Sharia banking employees are very helpful in my financial business / activities & 4.89 \\
\hline 3 & There is no discrimination in Sharia banking service. & 4.87 \\
\hline \multicolumn{3}{|c|}{ Responsibility in Working Criteria } \\
\hline 1 & Sharia banking employees need more education and training to increase their service quality. & 5.26 \\
\hline 2 & Education and training for Sharia banking employees can increase the efficiency of Sharia banking. & 5.24 \\
\hline 3 & Sharia banking has good value of accountability. & 4.85 \\
\hline \multicolumn{3}{|c|}{ Guarantee of Welfare Criteria } \\
\hline 1 & I choose Sharia banking services because I expect fair and equitable bussiness terms and conditions. & 4.91 \\
\hline 2 & Sharia banking workers work, based on the time that has been specified by their corresponding banks. & 4.87 \\
\hline 3 & I (as a customer) have a freedom to make choice about Sharia banking products. & 4.85 \\
\hline \multicolumn{3}{|c|}{ Guarantee Of Environmental Sustainaibility Criteria } \\
\hline 1 & Sharia banking has to educate workers to keep and take care of the environment. & 4.83 \\
\hline 2 & I choose Sharia banking because Sharia banks have social responsibility to keep the conservation of the environment. & 4.63 \\
\hline 3 & Each provision of implementation or financing, Sharia regard to the conservation of nature. & 4.56 \\
\hline \multicolumn{3}{|c|}{ Charity for Preservation of virtue Criteria } \\
\hline 1 & Sharia banking supports and helps funds of virtues (such as giving scholarships and helping the socio-religious activities) & 4.89 \\
\hline 2 & Sharia banking participates in relieving social problems (such as helping the poor, helping disasters' victims, etc.) & 4.89 \\
\hline 3 & I choose Sharia banking because Sharia banking has a good social responsibility to the society. & 4.86 \\
\hline
\end{tabular}

Source: Estimated from the survey data

From Table 5 above it can be observed that the customer perceptions about IBIs towards the selection items of CSR criteria of IBIs is high or agree in assessing CSR operational of IBIs in Aceh. The IBIs in Aceh, thus implement CSR accordance with CSR criteria of IBIs.

The customers IBIs selection phase of Islamic banking, based on CSR, IBIs criteria show the range of the score from 4.21 to 6.00 is counted high. This indicates that the user selection over Islamic banking also influenced by CSR of Islamic banking in Aceh.

Table 6: IPIs Selection Phase by The Islamic Banking User Based on CSR Criteria

\begin{tabular}{|l|r|r|r|}
\hline \multicolumn{1}{|c|}{ Criteria } & Mean & $\begin{array}{c}\text { Eminent Spouse } \\
\text { (Standard } \\
\text { Deviation) }\end{array}$ & Interpretation \\
\hline 1. Syariah Compliance & 4.94 & 0.91 & High \\
2. Equality & 4.85 & 0.79 & High \\
3. Responsible in work & 4.72 & 0.84 & High \\
4. Guarantee of Welfare & 4.57 & 0.98 & High \\
\hline
\end{tabular}


5. Guarantee of Enviromental Sustainability

6. Charity for Preservation of Virtue

\begin{tabular}{l|l|l|}
4.63 & 0.93 & High \\
4.86 & 0.93 & High \\
\hline
\end{tabular}

Source: Estimated from the survey data

According to the Table 6 above, all criteria show the high minimum. This shows that the customers' selection over IPI is influenced by the CSR worship of Islamic banking in Aceh.

\section{Analysis Customers Perception toward CSR Criteria in IBIs Aceh}

\section{Perceptions based on gender differences}

Analysis of the customers perception based on gender groups shown in Table 7.

Table 7: Independent sample t-test for Sharia Bank Customers Perception Based on Gender

\begin{tabular}{|l|l|l|l|l|}
\hline Gender & Min (M) & SD & Score t & Sig. \\
\hline Male & 247.48 & 23.12 & -3.73 & $0.00^{*}$ \\
Female & 256.23 & 23.68 & & \\
\hline \multicolumn{2}{|l|}{${ }^{*} p<0.05$}
\end{tabular}

Table 7 shows the mean scores and standard deviations for male $(M=247.48 ; S D=23: 12)$ and female $(M=$ 256.23; SD = 23.68). Based on the results of independent samples t-test $(t=-3.73, p=0.00)$, there is a difference in perception of customers of the IBIs are significant between male and female groups. The finding shows that the perceptions of the women customer is better than men based on mean values score.

\section{Perception differences based on age}

In addition to using a t-test to analyze the mean comparison, analysis of variance or ANOVA was applied to investigate whether there is significant difference in the two groups of samples or otherwise. Thus, one way ANOVA applied to examine the affect of age on the perceptions of the customers. The samples were divided into five groups according to age of the customers. Overall finding reported in Table 8 after assuming homogeneity of variances are met.

Table 8: One-way ANOVA Perceptions Based on Age Customers IBIS

\begin{tabular}{|l|r|r|r|r|}
\hline \multicolumn{1}{|c|}{ Ages } & Mean & SD & F & Sig. \\
\hline $16-20$ tahun & 246.69 & 22.61 & 0.168 & \\
$21-30$ tahun & 252.77 & 24.90 & \\
$31-40$ tahun & 250.52 & 24.24 & \\
$41-50$ tahun & 254.46 & 16.62 & & \\
50 tahun ke atas & 254.67 & 21.02 & & \\
\hline
\end{tabular}

Source: Estimated from the survey data

Based on the result reported in Table 8 resulted from ANOVA $(F=0.168, p=0.650)$, there is no significant difference across the age groups. The above finding demonstrates the level of perceptions among the different age group is the same.

\section{Perception differences based on level of educations}

One-way ANOVA was conducted to examine the influence of the level of education on the customers' perceptions. The samples are divided into seven groups according to the level of educational attainment of the customers, respectively. The finding has been reported in Table 9 after assuming homogeneity of variances met. 
Table 9: One-way ANOVA Perceptions Based on Level IBIs Customers Education

\begin{tabular}{|c|c|c|c|c|}
\hline Level of Education & Mean & SD & Nilai $\mathrm{F}$ & Sig. \\
\hline Primary School & 267.00 & 9.89 & 2.101 & 0.052 \\
\hline Junior High School & 247.00 & 14.79 & & \\
\hline Senior High School & 251.84 & 23.58 & & \\
\hline Diploma & 254.73 & 23.07 & & \\
\hline Bachelor & 252.98 & 23.60 & & \\
\hline Master & 241.97 & 25.56 & & \\
\hline Doktor (PhD) & 217.00 & 16.97 & & \\
\hline
\end{tabular}

Source: Estimated from the survey data

Based on Table $9(F=2.101, p=0.052)$, there is significant difference among the various educational groups. That is, the above finding shows that the level of perceptions among the groups were different.

\section{Perception differences based on income level}

One-way ANOVA was conducted to examine the effect of monthly income of the customers on their perceptions. The samples are divided into six groups, according to the highest level of income of the customers. The finding has been reported in Table 10, after assuming homogeneity of variances are met.

Table 10 : One-way ANOVA Perception Test Based on the Income Level of IBIs Customer

\begin{tabular}{|c|c|c|c|c|}
\hline Income & Mean & $\mathrm{SD}$ & F Value & Sig. \\
\hline 0 to1 million (1) & 253.16 & 24.22 & \multirow[t]{6}{*}{5.731} & \multirow[t]{6}{*}{$0.000^{*}$} \\
\hline More than 1 million to 3 million (2) & 254.45 & 20.91 & & \\
\hline More than 3 million to 5 million (3) & 253.85 & 24.36 & & \\
\hline More than 5 million to 7 million (4) & 230.95 & 30.89 & & \\
\hline More than 7 million to 9 million (5) & 236.22 & 22.24 & & \\
\hline More than 9 million (6) & 234.50 & 23.41 & & \\
\hline
\end{tabular}

Source: Estimated from the survey data

Based on Table $10(F=5,731, p=0.000)$, which had been reported above show that there is significant difference among each group.

Furthermore, post-hoc comparison using the scheffe test proved that there were significant mean differences in the three pairs of groups, they are the group that has no income to one million $(M=253.16 ; S D=24.22)$ and the group which has income more than 5 million to 7 million $(M=230.95$; $S D=30.89)$. Next, the group which has income more than 1 million to 3 million $(M=254.45 ; S D=20.91)$ and the group whose income is more than 5 million to 7 million $(M=230.95$; $S D=30.89)$ and the last is the group whose income is more than 3 million to 5 million $(M=253.85 ; S D=24.36)$ and group that had income more than 5 million to 7 million $(M=230.95 ; S D=30.89)$. These will be described in table 11 below:

Table 11: Post-Hoc Scheffe: Customers Perception of CSR IBIs Based on Income

\begin{tabular}{|c|c|c|c|c|c|}
\hline \multirow[t]{2}{*}{ Variable } & (I) & (J) & \multirow[t]{2}{*}{ Different Mean (I-J) } & \multirow[t]{2}{*}{$\mathrm{SD}$} & \multirow[t]{2}{*}{ Sig. } \\
\hline & \multicolumn{2}{|c|}{ income } & & & \\
\hline User perception Sharia & 1 & 2 & -1.29 & 2.739 & 0.999 \\
\hline Banking & 1 & 3 & -0.69 & 3.661 & 1.000 \\
\hline & 1 & 4 & 22.20 & 5.379 & $0.005^{*}$ \\
\hline & 1 & 5 & 16.93 & 8.001 & 0.484 \\
\hline & 1 & 6 & 18.65 & 9.679 & 0.592 \\
\hline & 2 & 3 & 0.60 & 3.408 & 1.000 \\
\hline & 2 & 4 & 23.50 & 5.210 & $0.001^{*}$ \\
\hline & 2 & 5 & 18.23 & 7.888 & 0.377 \\
\hline & 2 & 6 & 19.95 & 9.587 & 0.504 \\
\hline & 3 & 4 & 22.89 & 5.749 & $0.008^{*}$ \\
\hline
\end{tabular}




\begin{tabular}{|r|r|r|r|r|l|}
\hline & 3 & 5 & 17.63 & 8.254 & 0.473 \\
& 3 & 6 & 19.35 & 9.890 & 0.575 \\
& 4 & 5 & -5.27 & 9.146 & 0.997 \\
& 4 & 6 & -3.54 & 10.646 & 1.000 \\
& 5 & 6 & 1.72 & 12.183 & 1.000 \\
\hline
\end{tabular}

${ }^{*}$ Couples groups showed significant difference mean

Source: Estimated from the survey data

\section{Multiple Linear regression; the influence of the practices of CSR Criteria IBIs in Aceh}

In the study there were six deciding criteria which were chosen as the factors to the election of the IBIs (dependent variable); the Sharia compliance, equality, responsibility in the work, guarantees of welfare, guarantee of environmental sustainaibility and charity for preservation of virtue. Furthermore, the value of $\Delta \mathbf{R}^{2}$ (adjusted $R^{2}$ ) are examined to find out how much of the variation in dependent variable (criterion) can be explained by the regression model was significant at the 0.05 level. In addition, ANOVA test was applied. The explanation is described in the exposure Table 12 below.

Table 12: Results of Multiple Linear Regression Analysis of CSR Practices Criteria by Customer IBIs

\begin{tabular}{|c|c|c|c|c|c|c|c|}
\hline Criteria & $\mathbf{R}$ & $\mathrm{R}^{2}$ & $\Delta \mathbf{R}^{2}$ & $\mathrm{~F}$ & $\mathrm{~B}$ & $t$ & Sig. \\
\hline Constant & 0.912 & 0.831 & 0.828 & 322.013 & -5.384 & -5.018 & 0.000 \\
\hline 1. Sharia compliance $\left(X_{1}\right)$ & & & & & 0.091 & 5.025 & 0.000 \\
\hline 2. Equality $\left(X_{2}\right)$ & & & & & 0.096 & 3.256 & 0.001 \\
\hline 3. responsible for the work $\left(X_{3}\right)$ & & & & & 0.079 & 3.240 & 0.001 \\
\hline $\begin{array}{l}\text { 5. Guarantee of Environmental } \\
\text { Sustainaibility }\left(X_{5}\right)\end{array}$ & & & & & $\begin{array}{l}0.457 \\
0.095\end{array}$ & 11.688 & 0.000 \\
\hline $\begin{array}{l}\text { 6. Charity for Preservation of Virtue } \\
\left(X_{6}\right)\end{array}$ & & & & & 0.261 & 8.346 & 0.000 \\
\hline
\end{tabular}

Based on the Table 12 above, the results of the analysis show that that compliance of sharia (X1), equality (X2), responsible for the work (X3), guarantee of welfare (X4), Guarantee of Environmental Sustainaibility (X5) and Charity for Preservation of Virtue (X6) is forecasted to election IBIs. The $\Delta R^{2}=0.828$, meaning that $82.8 \%$ of the variance for the dependent variable (election IBIs) is described by a linear combination of these six criteria. The dominant criteria that influence the selection of IBIs for ccustomers of IBIs was observed with highest Beta coefficient, namely the guarantee of welfare $(\beta=0.457)$. That is a change of 1 standard deviation in guarantee of welfare was associated with changes in the selection of Standard Deviation 0.457 IBIs. The decision analysis results are a guarantee of welfare is the dominant criteria that influence the selection of IBIs for the customers of IBIS.

The Relationship between selections of IBIs with the perceptions of customers.

Table13: Correlation Analysis Pearson Test between the elections of IBIs with Perception Customers IBIs in Aceh

\begin{tabular}{|l|l|l|l|l|}
\hline Variable & Mean & SD & Pearson Correlation( $r$ ) & Sig. \\
\hline User perceptions of Sharia Banks Overall IBIS & 251.99 & 23.79 & 0.890 & $0.000^{*}$ \\
Selection & 33.49 & 4.38 & & \\
\hline & & & & \\
\hline
\end{tabular}

Source: Estimated from the survey data

Refer to Table 13 above, decision analysis correlation Pearson found the value of $r=0.890$ with $p<0.001$. This shows there is a significant relationship between the two variables. In addition, positive values also explained there was a significant positive relationship between score election IBIs with the perception of the practice of CSR criteria. The value 
of the correlation $r=0.890$ shows the correlation between the two different variables is very high. Variant of $r^{2}=0.79222$ also shows that $79.2 \%$ of the overall election IBIs caused by the perceptions of the customers against the practice of CSR criteria executed by IBI. This decision explains that the perception of the customers against the practices of CSR criteria executed IBIs has a relationship with the users of the IBI selection, where the relationship is strong or very high with $r=0.890$.

\section{Conclusion}

The four objectives of this paper are to identify the concept of CSR in Islamic perspective; to analysis and develop CSR criteria of IBIs; to analysis the stakeholders' perceptions of the Islamic Banking in Aceh and to assess the relationship between bank selection with perception of stakeholders Syari'ah banking in Aceh about practical criteria CSR of IBIs.

The study is divided into two phase. The first phase of the study is theoretical and library researches with used the content analysis method. The second phase is in the form of empirical research. It involved interviews with experts on the accuracy of the concepts, criteria and Islamic CSR items and also survey involving 400 customers of customers.

The findings of the study in the first phase shows verses in the Qur'an and the Sunnah which do not directly explain the concept of CSR, but there are many verses and hadith about individuals obligation to be responsible for social life. CSR concept in Islam is practiced in three areas of responsibility. First is the responsibility to God. Second is the responsibility towards the people, and third, the responsibility to the environment. Three forms of this task are supported by the basic principles of monotheism (tauhid), the caliphate (khalifah), justice, brotherhood (ukhuwwah) and the creation of maslahah. From these five principles, there are six criteria and 34 items established as the instrument to measure CSR performance of the IBIs. The six criterions are: Syariah compliance, equality, working responsibility, the guarantee of prosperity, the guarantee environmental sustainability and charity for preservation of virtue. As the findings of the second phase of the study indicate that the customers perception of the Syariah banking CSR practices in Aceh are high. The customers make Syariah compliance criteria as the main criteria in the selection of the IBIs. From the presence of satisfaction with the practice of CSR, $72.5 \%$ of customers feel satisfied. Findings of the study show that there is significant difference across the gender, education, monthly earning expect the age groups of the customers. In terms of correlation between the selections of the IBIS in customers' CSR to practices IBIs criteria are positive and significant correlation. While on the other hand, the guarantee of prosperity criterion is the dominant part of CSR criteria that influence the selection of customers. This study has produced a set of criteria that can be used IBIS CSR as a guide in conducting the operations of CSR in IBIS

\section{Bibliography}

Al-Qur'an.

Abdullah al Mushlih dan Shalah al Shawiy (1998), Prinsip-Prinsip Islam Untuk Kehidupan (terj), LP2SI Al Haramain, Jakarta.

Abu al A'la al Maududi (t.t), Al Hadarah al Islamiyyah: Ususuha wa Mabadi 'Uha, Kaherah: Dar Ansar.

Ahmad Azrin bin Adnan (2010), Penentu Pemilihan Institusi Perbankan Islam Dalam Kalangan Muslim di Terengganu, Tesis Ph.d. USM.

Asyraf Wajdi Dusuki dan Humayon Dar (2005), Stakeholder's Perceptions Of Corporate Social Responsibility Of Islamic Banks:

Evidence From Malaysian Economy", (Proceeding of The $6^{\text {th }}$ International Confernce on Islamic Economic and Finance, Vol. 1, Jakarta), p. 390.

Birch, D dan Moon, L (2004). Corporate Social Responsibility in Asia. Journal of Corporate Citizenship, Spring, 13, pp. 18-23.

Bowen, H.R. (1953). "Social Responsibilities of the Businessman, Harper \& Row, New York.

Carroll, A. (1999), Corporate Social Responsibility; Evolution of Definition Construct. (Business and Society, 38, 3), p. 264.

Carroll, A. (1999). Corporate Social Responsibility; Evolution of Definition Construct. Business and Society, 38 (3). 268.

Carroll, A. B. (1979). A Three-Dimensional Model of Corporate Performance. Academy of Management Review, 4 (4), pp. 497-505

Carroll, A. B.(1991). The Pyramid of corporate Social Responsibility: Toward the Moral Management of Organizational Stakeholders", Business Horizons, 34 (4), pp. 39-48

Clarkson, Max B. E. (1995), A Stakeholder Framework for Analysing and Evaluating Corporate Social Performance, (Academy of Management Review, 20. 1), p. 92-117.

Davies, J.A. (1971). Elementary Survey Analysis. New Jersey: Prentice Hall.

Davis, K. (1960). Can Business Afford to Ignore Corporate Social Responsibilities?. California Management Review. 2, 70-76.

Davis, K. (1967). Understanding The Social Responsibility Puzzle", Business Horizons 10(4), 45-51.

22 The interpretation of the strength of the correlation relationship is based on the classification scale Davies (1971). For the correlation between 0.01 to 0.09 is ignored. For the correlation between 0.10 to 0.29 is ignored. For the correlation between 0.30 to 0.49 is simple. For the correlation between 0.50 to 0.69 is high. And for the correlation between 0.70 and 1.00 is very high. 
Davis, K. (1973). The Case For And Against Business Assumption Of Social Responsibilities. Academy of Management Journal. Vol. 16. P $312-322$

Donaldson, Thomas, and Dunfee, Thomas W, (1994). Toward a Unified Conception of Business Ethics: Integrative Social Contracts Theory. Academy of Management Review. 19 (2), pp. 252-284.

Donaldson, Thomas, and Preston, Lee E. (1995). The Stakeholder Theory of the Corporation: Concept, Evidence and Implications. Academy of Management Review, 20 (1), pp. 65-91.

Frederick, et al. (1988), Business And Society, Corporate Strategy, Public Policy, Ethics, (Amerika Serikat: McGraw-Will), p.28.

Freeman, R. (1984). Strategic Management: A Stakeholder Approach. Boston: Pitman.

Ibn Kathsir (1996), Tafsir al Qur'an Ibn Katsir, Beirut: Al Maktabah al 'Asriyyah.

Ibn Taimiyah (1314 H), Al Hisbah fi Islam, Percetakan Al Muid, Mesir.

Muhammad Yasir Yusuf, Aplikasi CSR Pada Bank Sharia: Suatu Pendekatan Maslahah Dan Maqasid Sharia, Jurnal Ekonomi Dan Bisnis Islam, Vol. 4, No.2, Juni.

Musa Obaloha (2008), Beyond Philanthropy: Corporate Social Responsibility In The Nigerian Insurance Industry, Social Responsibility Journal, (Emerald Group Publishing Limited Vo. 4, No. 4), p. 538.

Rizk, et al., (2008), Corporate Social and Enviromental Reporting; A Survey of Disclosure Praktices in Egyp, Social Responsibility Jounal, (Emerald Group Publishing Limited), p. 306.

Robert Hay dan Ed Gray (1994), Social Responsiblity of Business Manager, Academy of Manajement Jounal Managing Corporate Sosial Responsibility, (Little, Brown and Company, Boston, Toronto), p. 9.

Sabitha Marichan (2006), Kaedah Penyelidikan Sains Sosial, Pearson Prentice Hall, Malaysia.

Sekaran, U (2003). Research Methods for Business: A. Skill Buiding Approace (4th ed.) New York: John Wiley \& Sons Inc.

Sekaran, U. (1992). Research Method for Business: a Skalal Building Approach. Ed. Ke-2. New York: John Willey \& Sons.

Suhaila binti Abdullah (2008), Isu Alam Sekitar Dalam Usaha Pembangunan Lestari di Universiti Sains Malaysia: Analisis Dari Perspektif Islam, Prosiding Seminar Fiqh dan Pemikiran Islam Lestari, 29-30 Oktober 2008, USM.

The Economist (2005), The Good Company: A Survey of Corporate Social Responsibility, (The Economist, January 22nd).

Wartick, S. L. and P. L. Cochran, (1985). The Evolution of the Corporate Social Performance Model. Academy of Management Review, 10(4), 758-69.

Wood, D. J. (1991). Corporate Social Performance Revisited', Academy of Management Review, 16(4), 691-718.

www.aaoifi.com

Zahari bin Mahad Musa (2008), Fiqh Al Biah: Prinsip Pembangunan Komuniti dengan Alam Persekitaran Yang Lestari, Prosiding Seminar Fiqh dan Pemikiran Islam Lestari, 29-30 Oktober 2008, USM.

Zikmund, Willian. G., (2000) Business Research Methods, Fort Worth: Dryden Press 